\title{
Willingness to Pay for Nature Conservation Policies in State-Owned Forests: An Austrian Case Study
}

\author{
Michael Getzner ${ }^{1, *}$, Jürgen Meyerhoff ${ }^{2}$ (D) and Felix Schläpfer ${ }^{3}$ \\ 1 Department of Public Finance and Infrastructure Policy, Institute of Spatial Planning, \\ Vienna University of Technology, 1040 Vienna, Austria \\ 2 Center of Landscape Economics, Institute of Landscape Architecture and Environmental Planning, \\ Technische Universität Berlin, 10623 Berlin, Germany; juergen.meyerhoff@tu-berlin.de \\ 3 Department of Business and Management, Kalaidos University of Applied Sciences, 8050 Zürich, \\ Switzerland; felix.schlaepfer@kalaidos-fh.ch \\ * Correspondence: michael.getzner@tuwien.ac.at; Tel.: +43-1-58801-280320
}

Received: 2 July 2018; Accepted: 31 August 2018; Published: 1 September 2018

\begin{abstract}
The Austrian Federal Forests (ÖBf), the Republic of Austria's state-owned company, manages $15 \%$ of the Austrian forests; about $50 \%$ of the land is devoted to nature conservation. This paper presents the results of a representative survey of Austrian households ascertaining the acceptance of, preferences regarding, and willingness to pay for three different management scenarios. One program would increase commercial forestry, while two other programs would significantly enhance biodiversity conservation. The majority of respondents considers it an important task of state-owned forests to enhance biodiversity conservation. The study reveals that the preferences of the respondents are very heterogeneous. For instance, in addition to socio-economic characteristics, the willingness to pay for nature conservation depends on personal experiences and perceptions (e.g., whether respondents feel anxious in forests), political views (e.g., the acceptance of strict legal protection of natural resources), and opinions on forest policy issues (e.g., preferences regarding privatization of public land). The study places special emphasis on the thorough description and presentation of the scenarios to the respondents and is one of the first European studies to elicit opinions on forest policies regarding public land in an environmental valuation framework.
\end{abstract}

Keywords: state-owned forests; Austria; commercial forestry; nature conservation; willingness-to-accept/ willingness to pay; scenario design

\section{Introduction}

Conserving forest environments is certainly a key issue in enhancing biodiversity. Forests cover almost $50 \%$ of land in Austria, with another $15 \%$ of land in high-alpine regions, leaving only some $35 \%$ of land to agricultural, residential, and commercial and infrastructure purposes [1]. The Austrian Federal Forests (Österreichische Bundesforste, ÖBf) is the Republic of Austria's state-owned forest company [2]. The ÖBf manages about $10 \%$ of Austrian land and $15 \%$ of Austrian forests. Municipalities and regional governments own about $3 \%$ of the Austrian forests; about $10 \%$ of the forests are owned by cooperatives, leaving about $72 \%$ of the forests to private ownership. The state does not only define the regulatory frameworks of nature conservation and forestry for private (individual and corporate) forest and land owners. The state is also a key stakeholder, managing a substantial share of Austrian land. For quite some time, the public debate has concentrated on the question of whether the state-owned forests should aim at pursuing commercial forestry and contributing their profits to the government's budget, or at functioning as a blueprint for sustainable forest management by implementing nature conservation policies. The latter is of specific importance, because national governments, regions, 
municipalities, or other public institutions own about $40 \%$ of the European forests. The European State Forest Association (2018) reports that 17\% of state-owned forests are protected [3]; about 16\% of state-owned forests are designated as Natura 2000 areas. The differentiation between private and state-owned forests is not as clear-cut; however, cooperatives, municipalities, or other non-profit organizations may also own forest land (cf. [4]). In any case, all the forests are subject to national legislation (e.g., with regard to timber harvesting) and the distribution of property rights (cf. [5]).

The Austrian Federal Forests (ÖBf) have committed themselves to the concept of "multifunctional forestry" [6]. Similar programs and strategies can be found in many state-owned forests in Europe, such as in the Czech Republic, where about $77 \%$ of forests are owned by the state (central, regional, or local governments, including municipalities) [7]. Besides sustainable forestry, state-owned forests may aim at enhancing biodiversity and ecological stability and promoting education and research. In Germany, the central government, the German Länder, and municipalities, own about $42 \%$ of the forests. Integrated forest and biodiversity management form constituting elements of the country's forest policies.

There are therefore manifold aims of ÖBf's forest and land management (data and statistics from Getzner et al., 2018a [8]). The most important forest functions and commercial and non-commercial uses of forests are as follows:

- Forest management in commercial forests on about $65 \%$ of forest land (i.e., about $40 \%$ of total ÖBf land; not all ÖBf land consists of forests);

- Management and conservation of protected forests on about $30 \%$ of forest land (i.e., about $18 \%$ of ÖBf land); and

- Nature conservation according to a whole range of categories of protected areas, such as wilderness areas, core and buffer zones of national parks, Natura 2000 areas, and nature protection and landscape conservation areas [9]; such areas currently cover about 50\% of ÖBf land.

It must be noted that some of these functions are overlapping; for instance, commercial forestry may also take place in protected forests or in certain forests that are less stringently protected (e.g., landscape conservation areas).

Owing to these diverse aims and functions of the Austrian Federal Forests (ÖBf), the ecosystem services (ES) secured and provided by ÖBf cover almost all the ES categories listed in the European Environment Agency's CICES (Common International Classification of Ecosystem Services) classification of ecosystem services [10]. For instance, the provision of ecosystem services includes biomass use, such as timber and water from springs. The regulation and maintaining ecosystem services include erosion control, flood risk reduction, pollination services, and climate regulation. Recreation and non-use values, such as existence, option, and bequest values related to the conservation of biodiversity, are all important elements of cultural ecosystem services. As Gantioler et al. (2014) have shown, the benefits of conserving biodiversity within the Natura 2000 network substantially exceed the costs of establishing the network [11] (see also [12]).

For some of these ecosystems services, there are trade-offs in terms of improving the quantity and quality of one ES at the cost of diminishing another (cf. [13]). For instance, intensive commercial forestry and timber harvesting certainly reduce biodiversity conservation. Commercial forestry in protected forests may reduce the protective function of such forests and thus may necessitate technical substitution measures [14]. Enhancing biodiversity conservation, in turn, may reduce the opportunity for forest-based recreation, owing to restrictions of access to core areas of conservation.

The aforementioned concept of "multifunctional forestry" is ÖBf's strategy of trying to reconcile the different aims and objectives by conserving biodiversity on about $50 \%$ of ÖBf land while harvesting timber sustainably in commercial forests in other areas. However, recent developments challenge this concept, such as, the permanent loss of biodiversity, climate change, and the renewable energy strategies adopted at the national, as well as at the European Union (EU) level. In order to establish reliable information with regard to the preferences of citizens towards nature conservation and forestry, 
this paper presents the results of a representative survey of Austrian households. The survey deals with the acceptance of and willingness to pay (WTP) for possible forestry and nature conservation scenarios that ÖBf may pursue in the near future. As such, this paper deals with the elicitation of non-use values of biodiversity conservation (e.g., existence values), while the scenarios, of course, also influence use values such as recreation (for details see [15]). In addition to the socio-economic characteristics of the respondents influencing their personal answers, the survey specifically addresses their personal perceptions of forests and the forest policy context. The survey furthermore includes two methodological experiments. The first one tests for the influence of information with regard to stakeholder positions in forest policies. The second deals with an anchoring test in order to correct for the potential anchoring effects of the WTP bids presented to the respondents by means of payment cards.

This study, therefore, provides new insights into preferences for nature conservation and forestry in state-owned forests. As will be shown below, studies on state-owned forests are quite rare. To date, there is no such research for the Austrian context. In addition, this paper presents carefully drafted scenarios combining both qualitative and quantitative descriptions of environmental programs that are highly specific to the national context. Two methodological questions are also dealt with in the framework of environmental valuation (contingent valuation). The findings suggest that preferences and environmental values, expressed as the willingness to pay of citizens for nature conservation in state-owned forests, are heterogeneous and can only be transferred to other local contexts (policy sites) if the data on these heterogeneous preferences are available.

The structure of the paper is as follows: Section 2 provides a brief overview of the literature on several empirical and methodological issues with regard to the valuation of biodiversity conservation in state-owned forests. Section 3 presents the method and design of the contingent valuation survey. Section 4 describes the descriptive and econometric results. The results are discussed and summarized in Section 5, and conclusions are drawn.

\section{A Brief Literature Review of the Empirical and Methodological Issues}

The economic valuation of ecosystem services specifically rests on the "marginal change" in the environmental quality brought about by such services [16-18]. The value of the stock of natural capital, including ecosystems, ecological processes, and the single elements of ecosystems, such as plant and animal species, is usually not subject to valuation. The flow of services constitutes ecosystem services that benefit human needs in their widest sense (cultural, social, and consumptive needs). The aim of the environmental valuation is therefore to ascertain the values of changes of flows of ecosystem services (e.g., [19]). However, scholars have shown that the measurement and change of biodiversity is itself a complicated task, given the diverse metrics for biological diversity and the problems associated with changes in these metrics (e.g., [20,21]).

With respect to non-use values (existence and bequest values), it is a challenging task to value (marginal) changes of ecosystem services. Usually, researchers offer environmental policy programs to respondents in representative surveys and ask them to value these changes. While there is still a debate on the validity and reliability of such stated preferences (SP) and values elicited in contingent valuation (CVM) or choice experiments (CE), Johnston et al. (2017) have recently provided a comprehensive framework of best practice recommendations for designing such experiments [22]. With regard to the descriptions of the scenarios to be valued, Johnston et al. ([22], (p. 327)) have stated the following: "SP questionnaires should clearly present the baseline (or status quo) condition(s), the mechanism of change, and the change(s) to be valued and should elicit evidence that these pieces of information are understood, accepted, and viewed as credible by respondents. Both objective information and subjective (respondent) perceptions of this information should be considered". As described below and in the appendix of this paper, the valuation of the non-consumptive ecosystem services of the forests in Austria relies on a thorough description of the changes to biodiversity if the Austrian Federal Forests (ÖBf) were to realize one of the three scenarios. Therefore, the descriptions of the environmental 
policy programs provided information on the status quo and the changes brought about by the nature conservation policies at issue, including the mechanisms of provision. The pre-tests and focus group discussions made sure that the respondents understood and accepted the information provided and the programs offered.

Records of the experiences in other countries with regard to the valuation of the changes to the biodiversity in state-owned forests are rather scarce. Landscape preferences are also significantly important for valuing forest biodiversity [23]. However, there is only scattered empirical evidence on the perception and value of forest policies in state-owned forests. Bopa et al. (2013) studied the effects of sustainability practices in state-owned forests that constituted important parts of protected areas in Romania [24]. Their scenario description assumed several instruments of policy implementation, such as compensation for private landowners around state-owned forests and several intensities of conservation according to categories of protected areas. However, the focus of this Romanian study was on the revenues of timber production and the changes thereof. In addition, the authors only addressed one scenario and compared it with a "business-as-usual" baseline.

Bösch et al. (2018) ascertained the value of ecosystem services provided by German forests. In total, the annual value of the ecosystem services provided by one hectare of forest amounted to about $€$ 319. State-owned forests have a specific responsibility to secure these ecosystem services, because "state (and communal) forest enterprises could supply those forest ES that are not provided by private forest owners" [25].

Ciesielski and Sterenczak (2018) reviewed factors driving the perception of and preferences for forests in Europe. The important factors in their analysis were individual characteristics (such as age and income), tree stand characteristics (such as age and species composition), and human impacts on forests [26]. Nielsen et al. (2007) used a choice experiment to assess the willingness to pay for species composition, height structure, and standing and fallen dead trees in Danish forests. The willingness to pay for nature-based forest management (broad-leafed forest with trees of various heights and some dead wood instead of even-aged conifers) was $€ 262$ per household in a program that would cover all Danish forests [27]. Weller and Elsasser (2018) found similar results with respect to the benefits of the biodiversity of forests [28].

Rambonilaza and Brahic (2016) used a choice experiment to estimate the willingness to pay for forest attributes in publicly owned forests representing $15 \%$ of all the forests in France. The examined attributes were as follows: the forest stand structure and age distribution, the volume of fallen deadwood, and the presence of trees of high ecological value. The mean estimated welfare effect for biodiversity-friendly forest management in state-owned forests, compared with an even-age one-species coniferous forest with no deadwood, was $€$ 90-100 per household [29].

From an international perspective, state-owned forests in developing countries may certainly contribute significantly to the livelihood of the local residents, depending on the non-cash income from using natural resources. The study by Jagger et al. (2011) ascertained the local importance of state-owned forests in comparison with community or private forests [30]. While the empirical results are less relevant for Austria, the results indicated that the enforcement of management principles and the definition and allocation of property rights are of high importance. The diverse national frameworks of using forests for recreation support this conclusion. For instance, national laws in many European, especially Scandinavian, countries guarantee open and free access to forests and some forest products (such as mushrooms and berries) [5]; this also applies to forests in Austria.

\section{Methods: Empirical Survey and Presentation of Scenarios}

In June 2015, a comprehensive and representative household survey elicited Austrian households' perceptions of, recreational use, and willingness to pay for a range of possible scenarios of forest management by the Austrian Federal Forests (ÖBf). The sample consisted of 1501 respondents randomly selected according to a statistical quota in a certified household panel by Austria's largest online survey company, MarketAgent. The sample was stratified (with quotas) according to gender, 
age, income, and regional distribution (Austrian federal provinces). In total, 19,983 households were contacted; 2281 interviews were started (response rate 11.4\%) of which 1501 were completed. Owing to age or local residence, 28 invitations were excluded, 322 interviews were not counted due to already fulfilled socioeconomic quotas, and 430 interviews were terminated (termination rate $18.4 \%$ ). The sample was representative of the Austrian population with respect to age, gender, and regional distribution (residence of respondents). For instance, the mean age of the respondents was 42.8 years (statistical average of the Austrian population: 42.5 years). The share of female respondents was exactly 50\% (Austrian population: 50.87\%). 19.5\% of the respondents only held a primary school degree (Austrian population: 19.1\%; note that all figures are the authors' own calculations and official data from the Austrian statistical office, respectively; further information is provided in [8]).

Getzner et al. (2018b) presented and discussed the results of the survey with respect to use values of recreation in Austrian forests [15]. This paper concerns the willingness to pay of the respondents for three options of forest management with respect to the non-use values provided by these management options.

In order to facilitate the valuation exercise, the survey included blocks of questions regarding the respondents' perceptions of forest management and forest policies, use of forests for different types of recreation, and comprehensive information about the various development options. Without going into too much detail about the questionnaire, the element of the questionnaire that was most crucial for understanding the different options of forest management was the visual presentation of forests in different ecological states (from natural and virgin forests to artificial, intensively used forests; cf. [31]). Appendix A includes a detailed description of the scenarios presented to the respondents.

Figure 1 presents the visualizations of the different types of forests and their ecological states (i.e., degrees of 'naturalness'). The respondents were asked about their opinions of the forest closest to their homes; $61 \%$ of the respondents stated that "their" forest was in a "good ecological status" while $14 \%$ thought that the forest would be a natural (or even close to a virgin) forest. In order to elicit the respondents' willingness to pay for the different scenarios (programs) described below, the survey employed a contingent valuation with a payment card.

In addition, the questionnaire included two methodological experiments. First, owing to the length of the questionnaire and the wide range of topics raised, a payment card presenting a range of bids was used to elicit the willingness to pay of the respondents (see Appendix A). However, in order to avoid an anchoring effect of the willingness-to-pay bids, we drafted two payments cards with different bids and randomly assigned the respondents to one of two groups based on the type of payment card provided.

Second, we were also interested in the influence of stakeholders and peer-groups on the respondents' acceptance of the programs and willingness to pay. The questionnaire thus included several statements of stakeholder groups for half of the sample of respondents (see Appendix B). The online survey recorded whether the respondents asked for more information on the programs. Schläpfer (2011) and Getzner (2012) stressed the importance of peer groups and stakeholders in forming preferences [32,33]. While scholars have addressed the issue of information on WTP for biodiversity conservation in public forests (e.g., [34]), more information provided by stakeholder groups does not necessarily increase the acceptance of nature conservation programs or the amount of WTP bids. Rather, the respondents might be more aware of the scarcity of resources and the necessity to harvest resources (for instance, renewable energy sources produced by forests). 


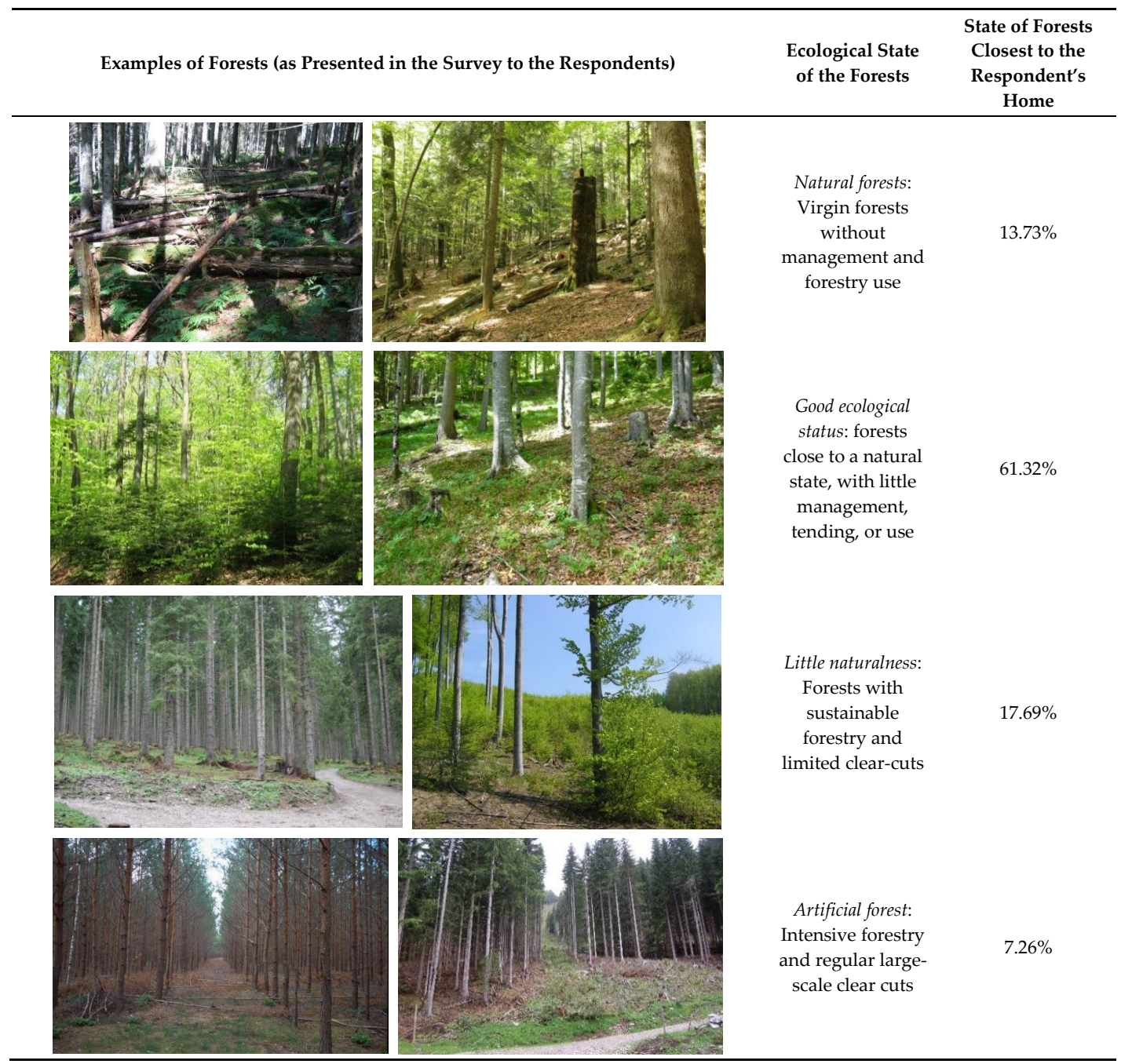

Figure 1. Visualization of the different ecological states of forests.

The survey included several scenarios of forest management that the Austrian Federal Forests (ÖBf) may pursue. Scholars have stressed that a detailed description of the change in biodiversity (e.g., change of species, ecosystem components, and ecological processes) is of high importance for eliciting valid and reliable estimates (e.g., [35]). Appendix A includes the scenarios as included in the questionnaire. The effects on the composition of the land of the Austrian Federal Forest in terms of nature conservation are presented in Figure 2. In short, three scenarios were offered to the respondents.

Program A: This scenario assumes that the Austrian Federal Forests (ÖBf) leave the path of current multifunctional forest management and intensify commercial forestry at the cost of reduced conservation areas ( $40 \%$ of the land would be protected instead of the current share of $50 \%$ ) and a diminished stringency of nature conservation.

Program B: This option would increase nature conservation and reduce commercial forestry; in total, $66 \%$ of the land would be protected.

Program C: This program would nearly cease commercial forestry and transform the Austrian Federal Forests (ÖBf) into an institution managing nature conservation on about $86 \%$ of the land. Forestry would therefore be a minor field of activity of the ÖBf. While Program B would enhance biodiversity and nature-based recreation and tourism at the same time, Program $C$ might lead to restrictions of access in larger areas. 


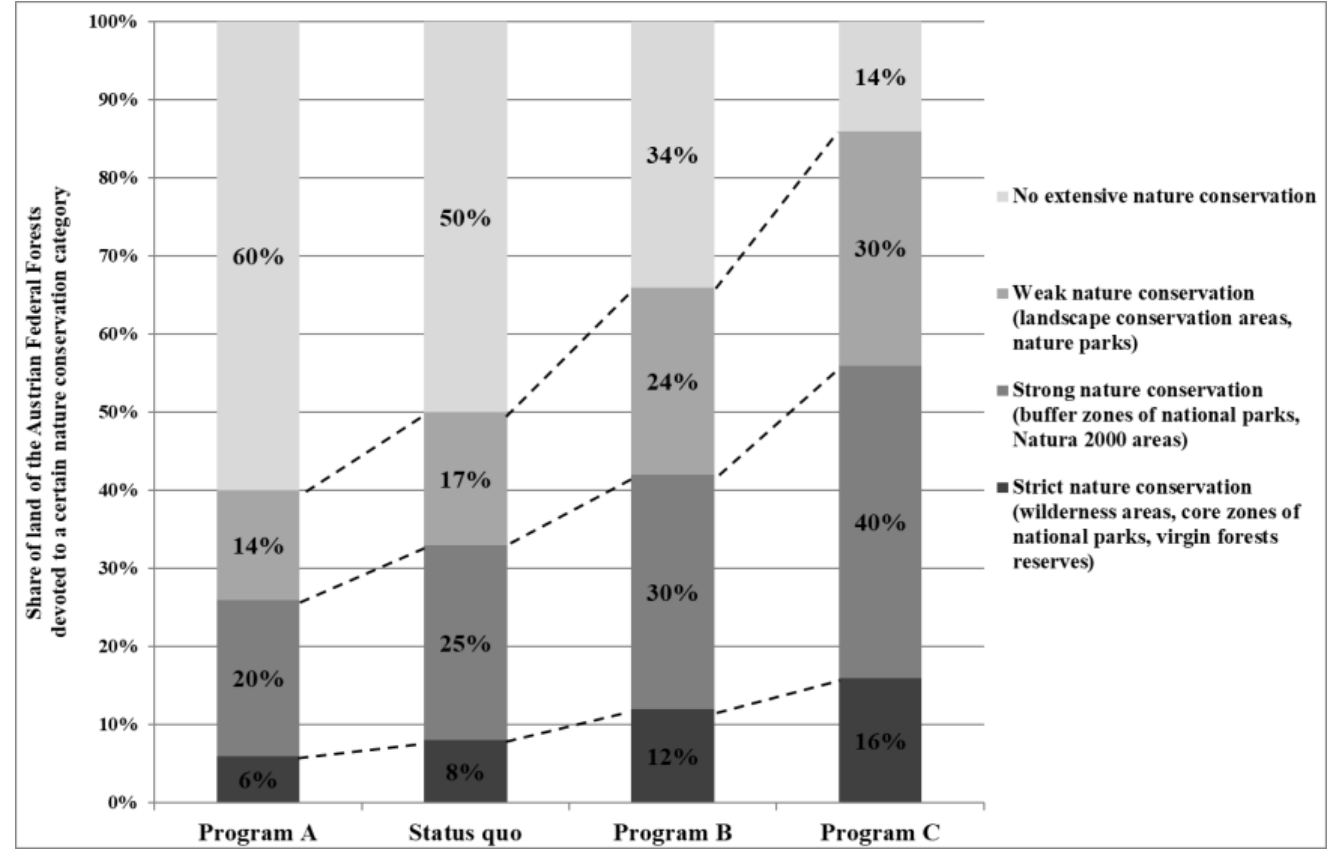

Figure 2. Presentation of the programs in the survey.

Table 1 below presents the dependent, as well as the explanatory, variables used; summary statistics of the dependent variables are shown in Table 2, and of all the other variables (including socio-economic characteristics) are displayed in Table 3.

Table 1. Overview of the variables of the descriptive and econometric analyses.

\begin{tabular}{|c|c|}
\hline Label & Description \\
\hline & Dependent variables \\
\hline $\mathrm{YN}_{\mathrm{A}}$ & $\begin{array}{c}=1 \text { for respondents explicitly agreeing to Program A or accepting compensation if } \\
\text { Program A would be realized }\end{array}$ \\
\hline $\mathrm{YN}_{\mathrm{B}}$ & $\begin{array}{c}=1 \text { for respondents explicitly agreeing to Program B or being willing to pay a positive } \\
\text { amount for Program B }\end{array}$ \\
\hline $\mathrm{YN}_{\mathrm{C}}$ & $\begin{array}{c}=1 \text { for respondents explicitly agreeing to Program } C \text { or being willing to pay a positive } \\
\text { amount for Program } C\end{array}$ \\
\hline $\mathrm{WTA}_{\mathrm{A}}$ & $\begin{array}{c}\text { Willingness to accept (compensation) if Program A were to be realized, } € \text { per } \\
\text { respondent (natural log) }\end{array}$ \\
\hline $\mathrm{WTP}_{\mathrm{B}}$ & Willingness to pay for Program B, $€$ per respondent (natural log) \\
\hline \multirow[t]{3}{*}{$\mathrm{WTP}_{\mathrm{C}}$} & Willingness to pay for Program $C, €$ per respondent (natural log) \\
\hline & Explanatory variables \\
\hline & $S_{i}$ (socio-economics) \\
\hline Age & Age (natural log) \\
\hline Gender & $=1$ for female respondents \\
\hline Kids & $=1$ for households with children \\
\hline Education & $=1$ for respondents with college or university education \\
\hline Income & $=1$ for respondent with a net household income larger than $€ 2000$ per month \\
\hline Member & $=1$ for respondents being a member of an environmental or nature conservation NGO \\
\hline Greens & $=1$ for respondents voting for the Greens in the next general election \\
\hline
\end{tabular}


Table 1. Cont

\begin{tabular}{|c|c|}
\hline Label & Description \\
\hline & $P_{i}$ (perception) \\
\hline High interest & $=1$ for respondents with a self-declared high interest in forest development and policies \\
\hline Distance & Distance to the next forest from the home of the respondents (kilometers, natural log) \\
\hline Very good state & $=1$ for respondents perceiving the state of Austrian forests as being very good \\
\hline \multirow[t]{2}{*}{ Improved state } & $\begin{array}{l}=1 \text { for respondents stating that the state of Austrian forests has improved significantly } \\
\text { in the last few years }\end{array}$ \\
\hline & $F_{i}$ (forests) \\
\hline Natural state & $=1$ if forests close to the respondent's home are perceived to be in a natural state \\
\hline Solitude & $\begin{array}{l}=1 \text { for respondents stating that they would find solitude in the forest closest to the } \\
\text { respondent's home }\end{array}$ \\
\hline Natural darkness & $=1$ if the closest forest is naturally dark \\
\hline Animal diversity & $=1$ for respondents finding a high animal diversity in the closest forest \\
\hline Plant diversity & $=1$ for respondents finding a high plant diversity in the closest forest \\
\hline Natural sound & $=1$ for respondents hearing only natural sounds in the closest forest \\
\hline \multirow[t]{2}{*}{ Natural smells } & $=1$ if natural smells are prevailing in the forests closest to the home of the respondent \\
\hline & $N_{i}$ (nature) \\
\hline Access bans & $\begin{array}{l}=1 \text { for respondents supporting access bans to natural environments owing to stricter } \\
\text { nature conservation policies }\end{array}$ \\
\hline Wilderness & $=1$ for respondents being fully comfortable in wilderness areas \\
\hline Forestry & $\begin{array}{c}=1 \text { for respondents stating that forestry is of high importance for the management of } \\
\text { forests and for providing renewable energy sources }\end{array}$ \\
\hline Natural heritage & $\begin{array}{c}=1 \text { if respondents stated that Austrian forests would be constitutive for the national } \\
\text { natural heritage }\end{array}$ \\
\hline Anxiety & $=1$ for respondents relating forests to anxiety and intimidation \\
\hline Ideal & $\begin{array}{c}=1 \text { if respondents thought that the current state of Austrian forests closely mirrored } \\
\text { their own imagination of an ideal forest }\end{array}$ \\
\hline Melancholy & $=1$ for respondents emotionally linking forests to a feeling of melancholy and solitude \\
\hline Austrian identity & $=1$ for respondents stating that Austrian forests contribute to the national identity \\
\hline Learning & $\begin{array}{c}=1 \text { if respondents stated that children's playing in forests is important for their } \\
\text { educational achievements }\end{array}$ \\
\hline \multirow[t]{2}{*}{ Instruction } & $\begin{array}{c}=1 \text { for respondents stating that kids' visits to forests teach them to responsibly care } \\
\text { for nature }\end{array}$ \\
\hline & $P_{i}$ (policies) \\
\hline $\begin{array}{l}\text { Polluter pays principle } \\
\text { Public task }\end{array}$ & $\begin{array}{c}=1 \text { for respondents agreeing to a strict polluter pays principle in environmental policies } \\
=1 \text { for respondents stating that the conservation of forests is a public task }\end{array}$ \\
\hline Bequest value & $\begin{array}{c}=1 \text { if respondents held strong bequest values with regard to natural forests for } \\
\text { future generations }\end{array}$ \\
\hline Strict regulation & $\begin{array}{l}=1 \text { for respondents stating that forests should be strictly protected regardless of } \\
\qquad \text { ownership (private or public) }\end{array}$ \\
\hline Protection irrespective costs & $\begin{array}{c}=1 \text { for respondents holding strong sustainability preferences (environmental protection } \\
\text { regardless the costs to society) }\end{array}$ \\
\hline Legal protection & $\begin{array}{c}=1 \text { for respondents stating that environmental protection is based on strict regulatory } \\
\text { frameworks and not on individual willingness to pay }\end{array}$ \\
\hline Austrian Federal Forests & $\begin{array}{l}=1 \text { if respondents stated that the Austrian Federal Forests should set a good example } \\
\text { for nature conservation }\end{array}$ \\
\hline \multirow[t]{2}{*}{ Privatization } & $=1$ for respondents agreeing to a full privatization of the Austrian Federal Forests \\
\hline & $M_{i}$ (methods) \\
\hline Split_paymentcard & $=1$ for the subsample of respondents with higher bids on their payment card \\
\hline Split_stakeholder & $\begin{array}{c}=1 \text { for respondents being offered statements of stakeholder groups before expressing a } \\
\text { willingness to pay }\end{array}$ \\
\hline
\end{tabular}


Table 2. Summary statistics of the dependent variables.

\begin{tabular}{cccc}
\hline & Mean & Std. Dev. & Median \\
\hline $\mathrm{YN}_{\mathrm{A}}$ & 0.421 & 0.494 & 0 \\
$\mathrm{YN}_{\mathrm{B}}$ & 0.755 & 0.430 & 1 \\
$\mathrm{YN}_{\mathrm{C}}$ & 0.606 & 0.489 & 1 \\
$\mathrm{WTA}_{\mathrm{A}}$ & 96.702 & 214.271 & 30 \\
$\mathrm{WTP}_{\mathrm{B}}$ & 29.600 & 62.599 & 20 \\
$\mathrm{WTP}_{\mathrm{C}}$ & 31.606 & 68.517 & 20 \\
\hline
\end{tabular}

Table 3. Summary statistics of the explanatory variables.

\begin{tabular}{|c|c|c|}
\hline Variable & Mean & Std. Dev. \\
\hline Age & 42.761 & 14.276 \\
\hline Gender & 0.502 & 0.500 \\
\hline Kids & 0.294 & 0.456 \\
\hline Education & 0.104 & 0.305 \\
\hline Income & 0.443 & 0.497 \\
\hline Member & 0.183 & 0.387 \\
\hline Greens & 0.085 & 0.279 \\
\hline High interest & 0.245 & 0.430 \\
\hline Distance & 4.561 & 5.300 \\
\hline Very good state & 0.113 & 0.316 \\
\hline Improved state & 0.308 & 0.462 \\
\hline Natural state & 0.503 & 0.500 \\
\hline Solitude & 0.099 & 0.299 \\
\hline Natural darkness & 0.107 & 0.309 \\
\hline Animal diversity & 0.207 & 0.405 \\
\hline Plant diversity & 0.262 & 0.440 \\
\hline Natural sound & 0.259 & 0.438 \\
\hline Natural smells & 0.710 & 0.454 \\
\hline Access bans & 0.426 & 0.495 \\
\hline Wilderness & 0.308 & 0.462 \\
\hline Forestry & 0.480 & 0.500 \\
\hline Natural heritage & 0.592 & 0.492 \\
\hline Anxiety & 0.047 & 0.212 \\
\hline Ideal & 0.285 & 0.451 \\
\hline Melancholy & 0.138 & 0.345 \\
\hline Austrian identity & 0.577 & 0.494 \\
\hline Learning & 0.441 & 0.497 \\
\hline Instruction & 0.594 & 0.491 \\
\hline Polluter pays principle & 0.691 & 0.462 \\
\hline Public task & 0.443 & 0.497 \\
\hline Bequest value & 0.744 & 0.437 \\
\hline Strict regulation & 0.595 & 0.491 \\
\hline Protection irrespective costs & 0.459 & 0.498 \\
\hline Legal protection & 0.617 & 0.486 \\
\hline Austrian Federal Forests & 0.509 & 0.500 \\
\hline Privatization & 0.109 & 0.311 \\
\hline Split_paymentcard & 0.500 & 0.500 \\
\hline Split_stakeholder & 0.500 & 0.500 \\
\hline
\end{tabular}

\section{Results: Descriptive and Econometric Evidence}

Table 2 below presents the rate of acceptance and valuation of the three scenarios. The overall results show that respondents rejected Program A (intensification of forestry) by about $58 \%$; or, the other way around, $42 \%$ of respondents would accept a program that would intensify forestry. However, the respondents would ask for a compensation of $€ 97$ per year in order to accept Program A. 
This average amount was much higher than the reduction of the tax burden by $€ 10$ per household according to Program A (Table 2).

Program B would be accepted by $76 \%$ of the respondents. While the average increase of the tax burden would be $€ 6$ per household per year, the mean annual willingness to pay amounted to $€ 30$ per household. Therefore, households might have a willingness to pay for Program B that is much higher than the actual proposed increase in taxes.

Finally, Program C was also favored by a majority of the respondents. Around $60 \%$ would also accept this program. However, households would have to pay $€ 20$ per year in additional taxes for the realization of this program. Their willingness to pay was only slightly higher than that for Program B and amounted to $€ 32$ per household per year. The median willingness to pay for both programs amounted to $€ 20$ per household. The respondents therefore would definitely accept Program B but might be somewhat hesitant with respect to Program C. While it is not straightforward to compare mean or median WTP for forest conservation policies between studies, it is interesting that Rambonilaza and Brahic (2016) presented willingness-to-pay figures for forest conservation programs in the same range as this paper [34]. For instance, they arrived at a mean WTP of about $€$ 90-100 for households, that is, slightly higher than mean WTP for forest conservation in Austria's state-owned forests accounting for the average size of households.

Figure 3 presents the distribution of willingness-to-pay bids of the respondents. Roughly, about one-third of the respondents would not be willing to pay for Program B, while over $40 \%$ of the respondents would not be willing to pay for Program C. The effect of the scale (i.e., the amount of land protected) of the two programs is visible in Figure 3, because respondents are willing to pay smaller amounts for Program B than for Program C. These differences resulted in the slightly larger mean WTP for Program C compared with Program B.

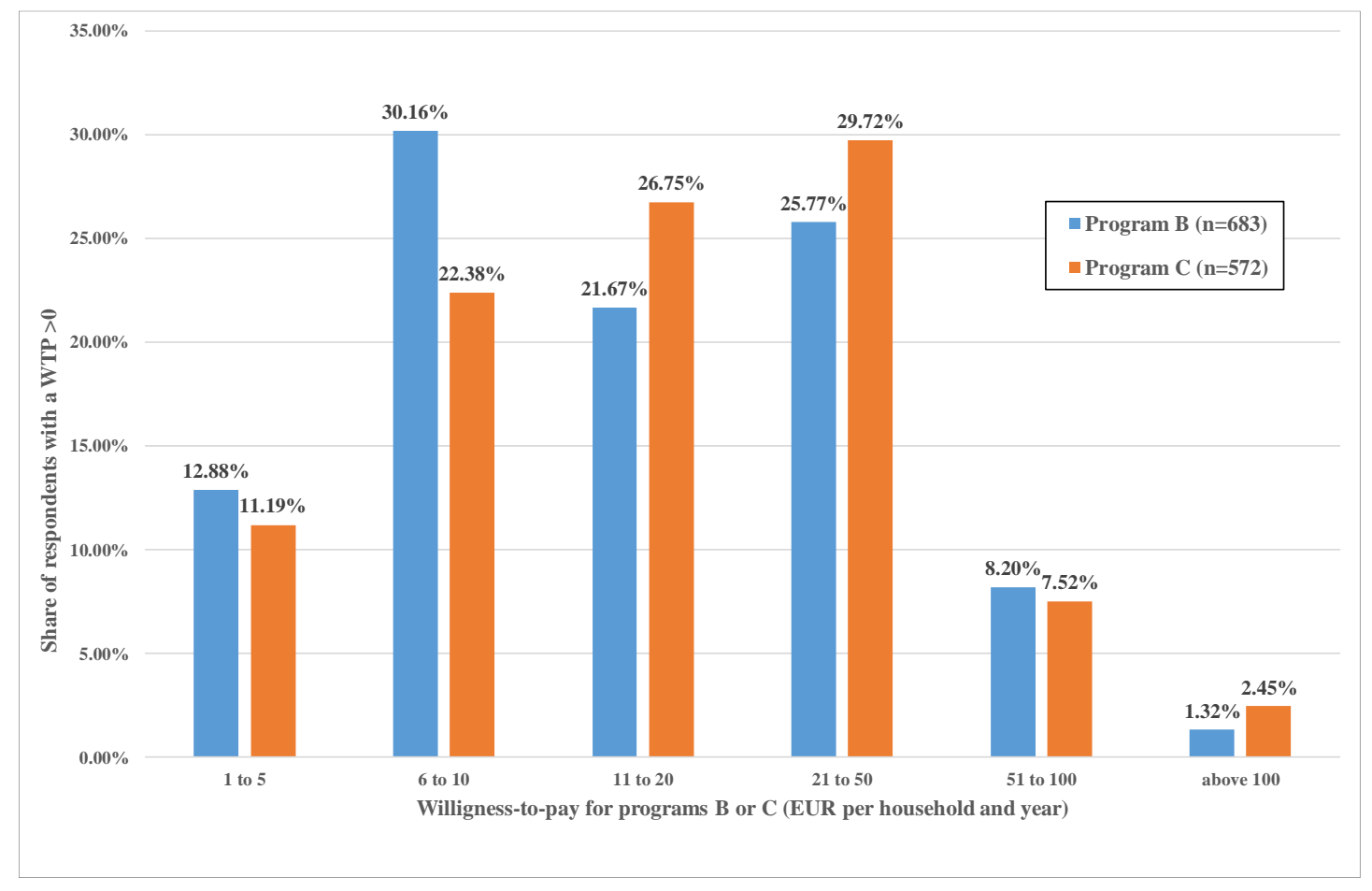

Figure 3. Distribution of the willingness to pay bids for Programs B and C.

Before turning to the summary of the statistics of all the explanatory variables included in the estimations, Figure 4 presents the degree of agreement of the respondents to certain personal statements with regard to forests, individual well-being, and child development. This degree of agreement is 
measured by the mean value of a 4 -point Likert scale ( $4=$ fully agree; $1=$ fully reject). The respondents held nearly unanimous opinions regarding the importance of forests for the Austrian image, natural and cultural heritage, and even national identity. However, it is interesting to consider that some respondents perceived forests as places of wilderness, melancholy, and even anxiety. This observation is also interesting in the context of the determinants of the respondents' willingness to pay for nature conservation according to Programs B or C presented below.

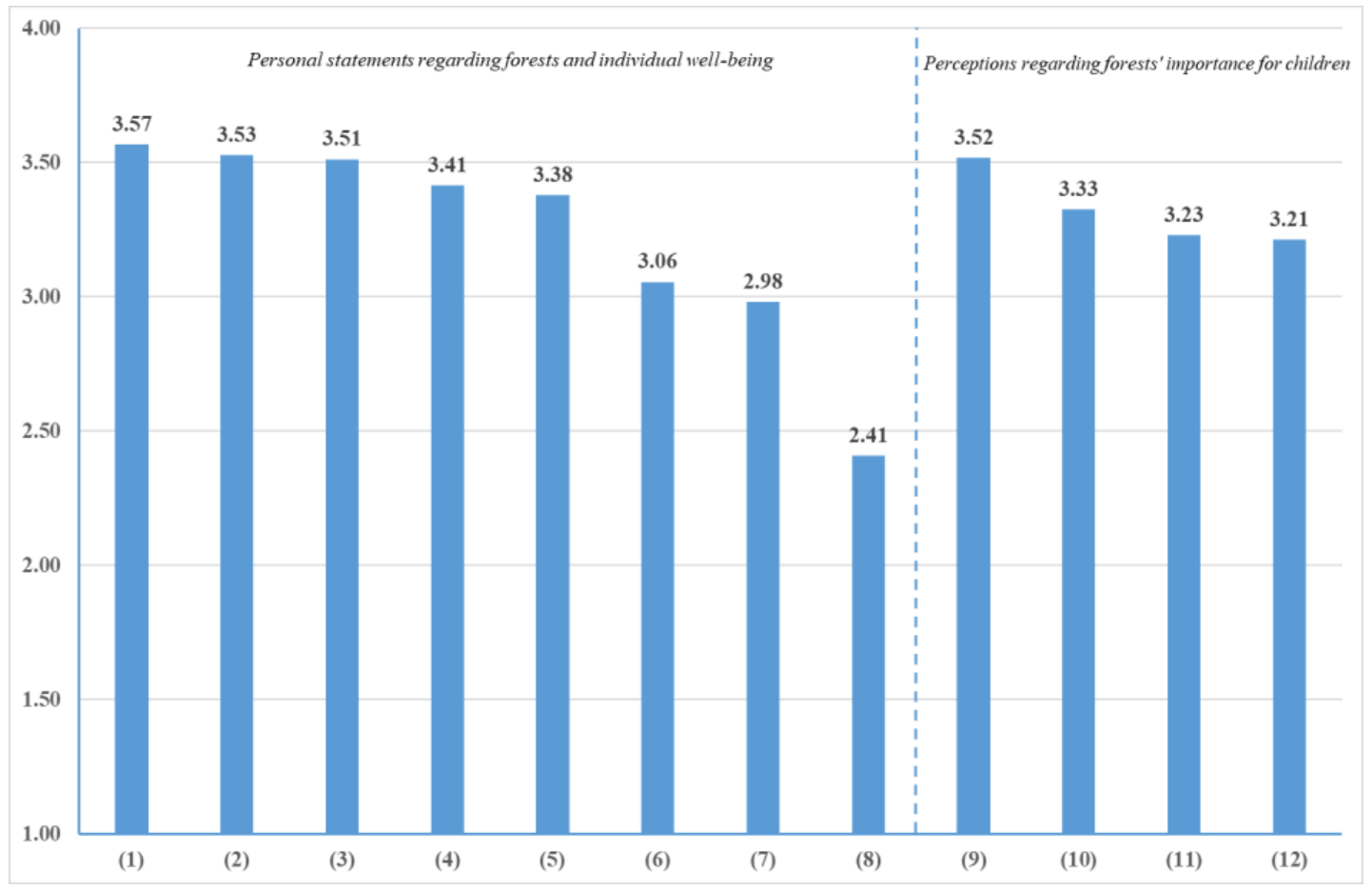

Figure 4. Agreement with personal statements and perceptions regarding forests. The items read: (1) Austrian forests are crucial for Austria's image; (2) Forests are vital for the natural heritage of Austria; (3) Typical forests contribute to Austria's identity; (4) Forests are vital for the cultural heritage of Austria; (5) Forestry is of high importance for the management of forests and for providing renewable energy sources; (6) Preferences for staying in natural forests (wilderness); (7) Regular activities in forests (1-2 times per month) are critical for my personal well-being; (8) Forests are closely related to melancholy and solitude; (9) Kids' visits to forests teach them to responsibly care for nature; (10) Importance of children's playing in forests for their educational achievements; (11) Kids fully develop their creativity in forests; and (12) Visiting forests are decisive for childhood development.

Regarding the importance of forests for child development, the respondents were also agreeing to statements stressing the need of children to play in forests and to discover and experience natural environments.

Regarding the options of forest policies, Figure 5 shows a range of mean values of the degrees of agreement of the respondents to the selected policy statements. In general, the respondents stated a high degree of agreement with policies towards conservation of the forests, the polluter pays principle, and the potential role of the Austrian Federal Forests as a flagship company to promote sustainable forest practices. In addition, a large majority of the respondents would accept bans of access to certain forest areas on the grounds of stricter nature conservation policies. Finally, it is also interesting to consider that the respondents were rather skeptical of the privatization of publicly owned forests. 


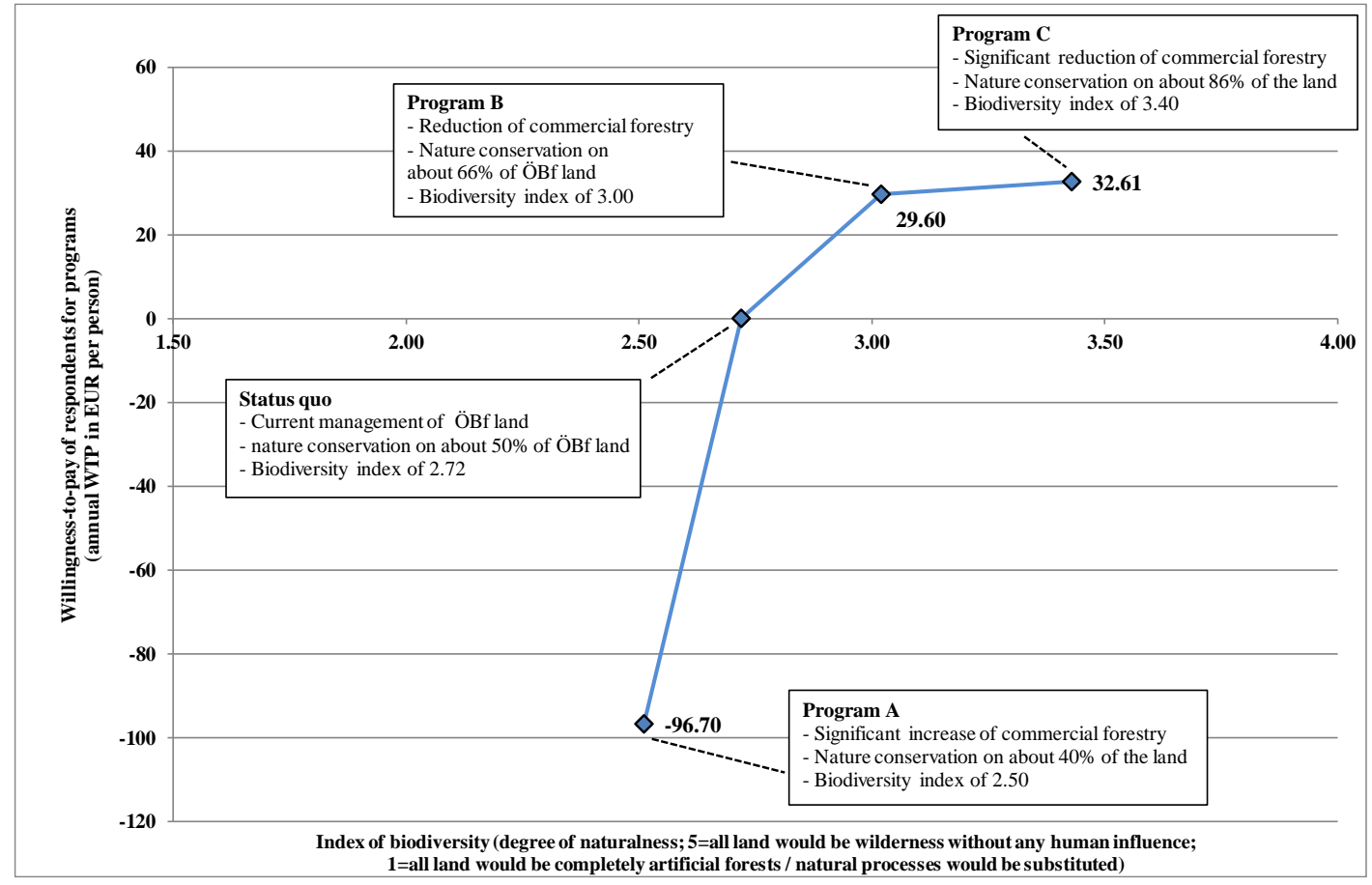

Figure 5. Relation between willingness to pay (willingness to accept) of forestry and nature conservation programs and the index of biodiversity (naturalness) achieved by the programs. ÖBf: the Austrian Federal Forests.

Before turning to the econometric estimation results, Table 3 presents a list of summary statistics of the explanatory variables in the econometric estimations. In addition to some socio-economic variables such as gender, education, age, and income, the variables cover a variety of personal statements regarding forests in general, childhood experiences and education, and forest policy issues. The main reason behind the inclusion of this wide range of variables was to test a comprehensive model of the willingness to pay bids of the respondents. Therefore, the motives and implicit elements of stating the willingness to pay bids were ascertained in order to compute the marginal willingness to pay for some of these variables. In order to facilitate a comparison of the estimated equations, all the variables were included in all the estimations. While the survey questionnaire included more questions, we only consider variables with significant coefficients in at least one of our estimations.

In order to analyze the potential correlations in greater depth, we now turn to the econometric analysis. We employed two econometric methods; a standard binomial logit model was used to test for determinants of accepting or rejecting a program. Furthermore, a Tobit model was used to account for the explanatory variables of the respondents' WTP (or WTA).

The first group of estimations (Table 4) explored the determinants of accepting or rejecting the respective program. In the following, we are not presenting every single estimation result but restrict the analysis to the most important empirical findings. The first column (Est. (1)) presents a standard binary logit estimation of the variable $\mathrm{YN}_{\mathrm{A}}$ ( $=1$ for respondents who would accept Program $\mathrm{A}$ ). The estimation shows that older respondents, women, and respondents potentially voting for the Green party in the next national election were less likely to accept Program A. Interestingly, the respondents who associated forests with wilderness, natural sounds, anxiety, and melancholy, were more likely to accept Program A, which would reduce the degree of naturalness of the forests. Regarding policy issues, the respondents with a preference for privatization were more likely to express an acceptance of Program A. 
Table 4. Determinants of the respondents' preferences for scenarios of forest and biodiversity development (computation by a standard binary logit estimation, maximum likelihood, extreme value; $\left.{ }^{* * *} p<0.01,{ }^{* *} p<0.05,{ }^{*} p<0.1\right)$.

\begin{tabular}{|c|c|c|c|c|c|c|c|c|c|}
\hline & \multicolumn{3}{|c|}{ Est. (1) } & \multicolumn{3}{|c|}{ Est. (2) } & \multicolumn{3}{|c|}{ Est. (3) } \\
\hline & \multicolumn{9}{|c|}{ Dependent Variable } \\
\hline & \multicolumn{3}{|c|}{$\mathbf{Y N}_{\mathrm{A}}$} & \multicolumn{3}{|c|}{$\mathrm{YN}_{\mathrm{B}}$} & \multicolumn{3}{|c|}{$\mathbf{Y N}_{\mathrm{C}}$} \\
\hline & \multicolumn{3}{|c|}{ (Acceptance of Program A) } & \multicolumn{3}{|c|}{ (Acceptance of Program B) } & \multicolumn{3}{|c|}{ (Acceptance of Program C) } \\
\hline & Coeff. & Z-Stat. & Prob. & Coeff. & Z-Stat. & Prob. & Coeff. & Z-Stat. & Prob. \\
\hline Constant & 2.689 & 3.327 & $* * *$ & 2.957 & 3.257 & $* * *$ & 1.040 & 1.277 & \\
\hline Age & -0.787 & -3.690 & $* * *$ & -0.757 & -3.166 & $* * *$ & -0.430 & -2.050 & $* *$ \\
\hline Gender & -0.272 & -1.783 & * & -0.010 & -0.061 & & 0.072 & 0.480 & \\
\hline Kids & 0.055 & 0.332 & & 0.029 & 0.158 & & 0.042 & 0.265 & \\
\hline Education & 0.233 & 0.944 & & 0.106 & 0.376 & & 0.415 & 1.704 & * \\
\hline Income & 0.052 & 0.349 & & -0.028 & -0.164 & & 0.144 & 0.961 & \\
\hline Member & -0.127 & -0.619 & & 0.559 & 2.280 & $* *$ & 0.568 & 2.858 & $* * *$ \\
\hline Greens & -0.693 & -2.279 & ** & 0.215 & 0.628 & & 0.283 & 1.037 & \\
\hline High interest & 0.030 & 0.168 & & 0.281 & 1.351 & & 0.212 & 1.179 & \\
\hline Distance & 0.197 & 1.884 & * & 0.033 & 0.289 & & -0.023 & -0.221 & \\
\hline Very good state & -0.281 & -1.149 & & -0.118 & -0.437 & & 0.043 & 0.192 & \\
\hline Improved state & 0.217 & 1.294 & & -0.219 & -1.215 & & -0.006 & -0.035 & \\
\hline Natural state & 0.180 & 1.107 & & 0.648 & 3.570 & $* * *$ & 0.147 & 0.913 & \\
\hline Solitude & 0.354 & 1.341 & & 0.347 & 1.223 & & 0.156 & 0.621 & \\
\hline Natural darkness & 0.261 & 1.055 & & 0.318 & 1.095 & & 0.673 & 2.637 & $* * *$ \\
\hline Animal diversity & 0.025 & 0.137 & & 0.268 & 1.210 & & 0.458 & 2.296 & $* *$ \\
\hline Plant diversity & 0.127 & 0.718 & & 0.133 & 0.661 & & 0.376 & 2.161 & $* *$ \\
\hline Natural sound & 0.416 & 2.320 & ** & 0.223 & 1.149 & & 0.457 & 2.515 & $* *$ \\
\hline Natural smells & 0.181 & 1.057 & & -0.134 & -0.686 & & 0.185 & 1.075 & \\
\hline Access bans & -0.258 & -1.576 & & 0.431 & 2.194 & $* *$ & 0.214 & 1.285 & \\
\hline Wilderness & -0.296 & -1.684 & * & -0.183 & -0.885 & & -0.001 & -0.007 & \\
\hline Forestry & 0.500 & 2.965 & $* * *$ & -0.332 & -1.749 & * & -0.460 & -2.749 & $* * *$ \\
\hline Natural heritage & -0.523 & -2.793 & $* * *$ & -0.118 & -0.559 & & 0.033 & 0.173 & \\
\hline Anxiety & 1.346 & 3.087 & $* * *$ & -0.144 & -0.324 & & -0.039 & -0.097 & \\
\hline Ideal & 0.247 & 1.382 & & -0.188 & -0.917 & & 0.043 & 0.249 & \\
\hline Melancholy & 0.531 & 2.157 & ** & -0.382 & -1.478 & & -0.137 & -0.571 & \\
\hline Austrian identity & -0.267 & -1.440 & & 0.058 & 0.275 & & -0.364 & -1.942 & * \\
\hline Learning & 0.068 & 0.378 & & 0.213 & 1.073 & & 0.051 & 0.293 & \\
\hline Instruction & 0.032 & 0.170 & & 0.252 & 1.213 & & 0.088 & 0.479 & \\
\hline Polluter-pays-principle & 0.133 & 0.723 & & -0.414 & -2.090 & ** & -0.458 & -2.538 & ** \\
\hline Public task & -0.203 & -1.192 & & -0.133 & -0.688 & & 0.122 & 0.715 & \\
\hline Bequest value & -0.527 & -2.459 & $* *$ & 0.450 & 2.083 & ** & 0.018 & 0.087 & \\
\hline Strict regulation & -0.022 & -0.115 & & 0.186 & 0.903 & & 0.017 & 0.096 & \\
\hline Protection irresp. costs & -0.387 & -2.141 & $* *$ & 0.331 & 1.559 & & 0.256 & 1.435 & \\
\hline Legal protection & 0.093 & 0.456 & & 0.478 & 2.277 & ** & 0.097 & 0.520 & \\
\hline Austrian Federal Forests & -0.118 & -0.620 & & 0.411 & 1.917 & * & 1.174 & 6.467 & $* * *$ \\
\hline Privatization & 1.000 & 3.985 & $* * *$ & -0.203 & -0.679 & & 0.139 & 0.541 & \\
\hline Split_stakeholder & -0.061 & -0.426 & & -0.399 & -2.478 & $* *$ & -0.247 & -1.716 & * \\
\hline McFadden $\mathrm{R}^{2}$ & & 0.134 & & & 0.113 & & & 0.124 & \\
\hline S.E. of regression & & 0.459 & & & 0.411 & & & 0.458 & \\
\hline Log likelihood & & -588.767 & & & -494.077 & & & -588.486 & \\
\hline Log likelih.-ratio (LR) stat. & & $182.598^{* * *}$ & & & $125.959^{* * *}$ & & & $166.901^{* * *}$ & \\
\hline$n$ & & 999 & & & 1001 & & & 1002 & \\
\hline$n$ (Yes) & & 421 & & & 756 & & & 607 & \\
\hline$n(\mathrm{No})$ & & 578 & & & 245 & & & 395 & \\
\hline
\end{tabular}

As mentioned above, a majority of the respondents would nevertheless reject Program A even if offered an average compensation of $€ 10$ per household. The explanatory power of the estimation was sufficient given the cross-section characteristics of the data.

In comparison to Program A, Program B (the modest nature conservation scenario) was more accepted by the younger respondents and the members of environmental NGOs. The acceptance of Program B (see Est. (2), second column in Table 4) also increased with the perception of forests being in a natural state, acceptance of bans of access owing to nature conservation policies, and strong bequest values. Stakeholder opinions did not have much influence in the decision to accept or reject Program A. In contrast, the respondents who were part of the subsample presented with the opinions of 
stakeholders and who retrieved such information, were less likely to accept Program B (see Appendix B for a description of the stakeholder opinions). In total, $76 \%$ of the respondents would accept Program B.

Acceptance rates were smaller for Program C (60\% of the respondents would vote in favor of Program C). However, as Est. (3) (the third column in Table 4) shows, the older respondents were less likely to accept Program C. While membership in an environmental organization contributed to the probability of accepting Program $C$ as did higher education. The respondents who had strong preferences for plant and animal biodiversity, natural sounds, and natural darkness, were more likely to accept Program C, as were respondents who stressed the important role of the Austrian Federal Forests as a model for sustainable forestry. Again, the respondents who received information on stakeholder opinions and who clicked on such information were more likely to reject the program.

Table 5 displays estimations with respect to the determinants of the respondents' willingness to accept (WTA Program A) and willingness to pay (WTP for Programs B and C). The results were generally in line with the theoretical expectations and numerous empirical studies indicating preference heterogeneity of the respondents and the significance of socio-economic variables (e.g., [35]). The willingness to accept Program A (Est. (4), first column of Table 5), for instance, is lower for female respondents and higher for voters of the Greens. While the coefficient of the income variable exhibited a positive sign, WTA appears not to depend significantly on income. The respondents who preferred biodiversity and natural sounds, as well as accepted access bans owing to stricter nature conservation, exhibited a higher WTA. In addition, those who perceived the forests as natural heritage and were in favor of stricter regulations would also ask for a higher compensation. While stakeholder opinions did not influence the respondents' WTA, the "anchoring variable" (variable Split_paymentcard) exhibited a significantly positive coefficient. Higher bids on the payment card increased willingness to accept, as expected.

Est. (5) of Table 5 (second column) shows that the respondents' willingness to pay for Program B, for instance, increased with income and education, with increased distance to the next forest, and with the generally perceived improvement of the natural state of forests. While WTP seems to be influenced somewhat by preferences towards wilderness and bans of access, the variable denoting melancholy felt by the respondents in forests reduced WTP. Again, the amounts presented on the higher payment card drove up the payments bids.

Finally, Est. (6) (third column) presents an estimation that exhibits the largest explanatory power of all the estimations. While some of the socioeconomic variables were again significant (e.g., higher income was connected with a higher willingness to pay), there seem to be other interesting determinants of WTP for Program C in comparison to the other estimations. For instance, the respondents who perceived forests to be in an already very good state decreased their willingness to pay. However, respondents who exhibited strong preferences towards access bans and wilderness also stated higher WTP bids. The feeling of melancholy again reduced the WTP bids. Finally, it seems that preferences, especially for Program C, were not only connected to one's own preferences and experience regarding forests but were also determined by opinions on forest policy issues. The respondents who favored nature conservation irrespective of the costs involved and who were strong advocates of the Austrian Federal Forests' (ÖBf) role in nature conservation exhibited a higher willingness to pay for Program C. The respondents who thought that forests were to be legally protected even if individual citizens were not willing to pay, exhibit smaller WTP bids. Again, the payment card with higher WTP bids also increased the respondents' WTP. 
Table 5. Determinants of the respondents' willingness to accept/willingness to pay with regard to scenarios of forest and biodiversity development (computation by a standard maximum likelihood Tobit model, extreme value; ${ }^{* *} p<0.01,{ }^{* *} p<0.05,{ }^{*} p<0.1$ ).

\begin{tabular}{|c|c|c|c|c|c|c|c|c|c|}
\hline & \multicolumn{3}{|c|}{ Est. (4) } & \multicolumn{3}{|c|}{ Est. (5) } & \multicolumn{3}{|c|}{ Est. (6) } \\
\hline & \multicolumn{9}{|c|}{ Dependent Variable: } \\
\hline & \multicolumn{3}{|c|}{ WTA $_{A}$} & \multicolumn{3}{|c|}{$\mathbf{W T P}_{\mathbf{B}}$} & \multicolumn{3}{|c|}{$\mathbf{W T P}_{\mathrm{C}}$} \\
\hline & \multicolumn{3}{|c|}{ (WTA of Program A) } & \multicolumn{3}{|c|}{ (WTP for Program B) } & \multicolumn{3}{|c|}{ (WTP for Program C) } \\
\hline & Coeff. & Z-Stat. & Prob. & Coeff. & Z-Stat. & Prob. & Coeff. & Z-Stat. & Prob. \\
\hline Constant & 4.296 & 6.077 & $* * *$ & 2.955 & 7.527 & $* * *$ & 2.091 & 5.289 & $* * *$ \\
\hline Age & -0.155 & -0.798 & & -0.113 & -1.086 & & 0.159 & 1.511 & \\
\hline Gender & -0.351 & -2.435 & $* *$ & -0.136 & -1.779 & * & -0.034 & -0.456 & \\
\hline Kids & 0.238 & 1.519 & & -0.021 & -0.265 & & -0.074 & -0.940 & \\
\hline Education & 0.445 & 1.866 & $*$ & 0.639 & 5.241 & $* * *$ & 0.376 & 3.403 & $* * *$ \\
\hline Income & 0.133 & 0.919 & & 0.224 & 2.979 & $* * *$ & 0.369 & 5.199 & $* * *$ \\
\hline Member & -0.744 & -3.720 & $* * *$ & -0.158 & -1.787 & $*$ & -0.221 & -2.752 & $* * *$ \\
\hline Greens & 0.641 & 1.860 & $* *$ & 0.148 & 1.144 & & 0.152 & 1.310 & \\
\hline High interest & 0.157 & 0.821 & & 0.009 & 0.099 & & 0.102 & 1.200 & \\
\hline Distance & -0.034 & -0.329 & & 0.106 & 2.100 & $* *$ & 0.020 & 0.397 & \\
\hline Very good state & -0.258 & -1.117 & & 0.094 & 0.738 & & -0.353 & -3.084 & $* * *$ \\
\hline Improved state & -0.040 & -0.249 & & 0.166 & 2.067 & $* *$ & -0.019 & -0.222 & \\
\hline Natural state & 0.182 & 1.161 & & -0.084 & -1.025 & & -0.047 & -0.590 & \\
\hline Solitude & -0.170 & -0.715 & & -0.079 & -0.645 & & 0.132 & 1.082 & \\
\hline Natural darkness & 0.004 & 0.017 & & -0.200 & -1.703 & * & -0.154 & -1.395 & \\
\hline Animal diversity & 0.099 & 0.550 & & 0.150 & 1.525 & & 0.029 & 0.313 & \\
\hline Plant diversity & -0.331 & -1.919 & $* *$ & 0.132 & 1.436 & & -0.053 & -0.593 & \\
\hline Natural sound & -0.525 & -3.028 & $* * *$ & -0.043 & -0.484 & & 0.012 & 0.128 & \\
\hline Natural smells & 0.276 & 1.634 & $\left({ }^{*}\right)$ & 0.176 & 1.940 & * & -0.113 & -1.344 & \\
\hline Access bans & -0.442 & -2.752 & $* * *$ & 0.150 & 1.794 & * & 0.367 & 4.619 & $* * *$ \\
\hline Wilderness & -0.287 & -1.578 & & 0.162 & 1.831 & * & 0.191 & 2.391 & $* *$ \\
\hline Forestry & -0.052 & -0.315 & & 0.002 & 0.029 & & -0.038 & -0.447 & \\
\hline Natural heritage & 0.715 & 3.756 & $* * *$ & 0.107 & 1.157 & & -0.145 & -1.562 & \\
\hline Anxiety & 0.052 & 0.178 & & 0.035 & 0.171 & & 0.115 & 0.593 & \\
\hline Ideal & 0.103 & 0.602 & & 0.011 & 0.126 & & -0.056 & -0.690 & \\
\hline Melancholy & -0.281 & -1.246 & & -0.199 & -1.677 & $*$ & -0.355 & -3.041 & $* * *$ \\
\hline Austrian identity & -0.116 & -0.660 & & -0.198 & -2.051 & $* *$ & -0.100 & -1.055 & \\
\hline Learning & -0.005 & -0.028 & & -0.091 & -1.053 & & -0.012 & -0.142 & \\
\hline Instruction & -0.189 & -1.098 & & 0.067 & 0.708 & & 0.085 & 0.899 & \\
\hline Polluter-pays-principle & -0.180 & -1.070 & & -0.175 & -1.966 & $* *$ & 0.095 & 1.101 & \\
\hline Public task & 0.348 & 2.077 & $* *$ & -0.010 & -0.122 & & 0.001 & 0.013 & \\
\hline Bequest value & -0.370 & -2.025 & $* *$ & 0.065 & 0.590 & & -0.147 & -1.316 & \\
\hline Strict regulation & 0.595 & 3.113 & $* * *$ & 0.036 & 0.371 & & 0.024 & 0.260 & \\
\hline Protection irresp. costs & 0.001 & 0.007 & & 0.331 & 3.421 & $* * *$ & 0.483 & 5.307 & $* * *$ \\
\hline Legal protection & -0.163 & -0.852 & & -0.122 & -1.217 & & -0.195 & -1.995 & $* *$ \\
\hline Austrian Federal Forests & 0.300 & 1.569 & & 0.223 & 2.250 & $* *$ & 0.291 & 3.028 & $* * *$ \\
\hline Privatization & -0.072 & -0.324 & & -0.142 & -1.107 & & -0.238 & -2.121 & $* *$ \\
\hline Split_paymentcard & 0.606 & 4.313 & $* * *$ & 0.425 & 6.008 & $* * *$ & 0.653 & 9.116 & $* * *$ \\
\hline Split_stakeholder & 0.212 & 1.497 & & 0.064 & 0.903 & & 0.142 & 2.073 & $* *$ \\
\hline McFadden $\mathrm{R}^{2}$ & & 0.097 & & & 0.103 & & & 0.161 & \\
\hline Log likelihood & & -657.936 & & & -928.215 & & & -704.782 & \\
\hline Avg. log likelihood & & -1.691 & & & -1.359 & & & -1.245 & \\
\hline Akaike info criterion & & 3.588 & & & 2.835 & & & 2.632 & \\
\hline$n$ & & 389 & & & 683 & & & 566 & \\
\hline
\end{tabular}

Finally, Table 6 shows the dependence of WTP with respect to the selected variables in terms of marginal WTP. For instance, if a respondent would change his/her perception of an improved state from denying that there has been an improvement to acknowledging the improvements, his/her willingness to pay would increase by $€ 4.87$ for Program $B$, all other things being equal. The respondents who would strongly prefer access bans versus those who do not exhibited an additional WTP of $€ 10.87$ for Program C, on average. 
Table 6. Willingness to pay for selected scenario attributes ( $€$ per respondent), based on scenarios B $\left(\mathrm{WTP}_{\mathrm{B}}\right)$ and $\mathrm{C}\left(\mathrm{WTP}_{\mathrm{C}}\right)$ (computation: marginal WTP was based on the coefficients of Est. (5) and (6) of Table 5; the elasticities were calculated by the following equation: $\varepsilon_{x}=\beta_{x} \cdot \bar{x} / \bar{y}$; the marginal WTP was computed by holding all other variables at mean values while changing the respective variable value from $0-1$; for mean values of the variables, see Table 3).

\begin{tabular}{ccc}
\hline & Est. (5) & Est. (6) \\
\hline & $\boldsymbol{\Delta} \mathbf{W T P}_{\mathbf{B}}$ & $\boldsymbol{\Delta} \mathbf{W T P}_{\mathbf{C}}$ \\
\hline Improved state & 4.87 & \\
Access bans & 4.29 & 10.87 \\
Wilderness & 4.75 & 5.69 \\
Melancholy & -5.25 & -8.99 \\
Polluter pays principle & -5.13 & \\
Protection irrespective costs & 9.55 & 14.25 \\
Legal protection & & -5.73 \\
Austrian Federal Forests & 6.32 & 8.34 \\
Split_paymentcard & 12.15 & 19.05 \\
$n$ & 683 & 566 \\
\hline
\end{tabular}

The respondents' feelings of strong melancholy during their presence in forests also had a WTP for the two programs that was lower by $€ 5-9$. Finally, we also included the sample split with respect to WTP bids on the payment card. While the WTP was about $€ 12$ higher for Program B, the higher bids on the payment card of Program C increased the WTP by about $€ 19$, which was substantial given the mean WTP of $€ 32$ per respondent.

While it is interesting to account for the willingness to pay (WTP) of the respondents for the different attributes presented in Table 5, the results of the current study support the design of other forestry and nature conservation policies as well. The results also facilitate estimating the welfare effects of different policies. The status quo, as well as the programs presented in this paper, lead to a different degree of naturalness (index of biodiversity conservation). The WTP of the respondents can, therefore, also be related to such indices (Figure 5).

Figure 5 shows a graphic representation of the relation between WTP (and willingness to accept, WTA) for the three programs valued by the respondents and the index of biodiversity (naturalness) that these programs would achieve. Getzner et al. (2016) computed this index based on data of every parcel of ÖBf land by taking into account a whole range of indicators describing the respective ecological state (model and assumptions as documented in [36]). Wilderness areas achieve the highest biodiversity index value of 5 , while completely artificial land without any natural processes in place has an index value of 1. For instance, ÖBf land currently has an index of naturalness of 2.72. Owing to the different policies and measures, Program B would increase this value to 3.00 , and Program C would achieve an index value of 3.40. Program A would reduce the index value to 2.50.

While our survey only elicited the WTP and WTA of the respondents for three specific programs, one may also use the results as a basis to design and value other programs. However, as shown, the functional form of the relationship remains unclear. The data points suggested a concave functional form (Figure 5). Using linear approximation, for instance, it is possible to estimate the value of other levels of protection within the range of the biodiversity levels evaluated in this study.

\section{Discussion and Summary}

The Austrian Federal Forests (ÖBf), the Republic of Austria's state-owned company managing $15 \%$ of the Austrian forests and, in total, about $10 \%$ of Austrian land, has already devoted about $50 \%$ of their land to nature conservation in different categories such as wilderness areas, national parks, and landscape protection areas. The aim of this paper is to present the key findings of a representative survey of Austrian households eliciting their preferences for nature conservation and forest policies for the publicly owned forests of ÖBf. 
A majority of the respondents $(58 \%)$ did not agree to a forest policy program that would significantly increase commercial forestry and reduce nature conservation to $40 \%$ of the total ÖBf land. However, the study revealed that there are mixed results with respect to programs that would significantly enhance nature conservation policies. We tested for two distinct conservation programs, one with a rather modest increase of nature conservation efforts (Program B with 66\% of ÖBf land under some nature conservation regime) and one with a strong focus on strict nature conservation policies (Program C, about $86 \%$ of ÖBf land would be protected). Both nature conservation scenarios gained a majority of the respondents (75\% for Program B, 60\% for Program C).

The respondents would have accepted Program A (significant increase of commercial forestry and reduction of nature conservation to $40 \%$ of ÖBf land) only under the condition that they received a compensation (willingness to accept) of $€ 97$ per person per year on average. This amount is much higher than the average hypothetical increase in profits of the Austrian Federal Forests by $€ 10$ per person. The individual benefits of the other programs exceeded the expected costs. The respondents were willing to pay around $€ 30$ per person for Program $B$, which is much higher than the potential loss of ÖBf profits of $€ 6$ per person per year that would result from the program. Program $C$ would attract a willingness to pay of about $€ 32$ per person per year, compared with a loss of $€ 20$ per person per year. Thus, both programs reducing commercial forestry and enhancing nature conservation reached a majority of the respondents. The willingness to pay was higher than the potential loss of profits for the Austrian Federal Forests if the programs were implemented.

There are a number of interesting results with regard to the acceptance of and the willingness to pay for the three programs.

- In general, there were several socio-economic determinants of the willingness to accept and pay for the programs; for instance, income, education, and voting behavior influenced the respondents' stated preferences. Thus, the willingness to pay rose with income, as expected.

- Not all respondents perceived forests as peaceful recreation areas. A minority of the respondents associated forests with anxiety, melancholy, and were afraid of only hearing natural sounds. If the respondents stated that they would feel such emotions in forests, both their acceptance of the nature conservation programs, as well as their willingness to pay, was significantly lower.

- The respondents who would accept the restrictions of access to forests owing to stricter nature conservation policies preferred the two programs with the aim to reduce commercial forestry on ÖBf land. They were also more likely to reject the program in which commercial forestry would be intensified.

- The variables codifying the different forest policies were important explanatory variables in the econometric estimations. For instance, preferences towards the strict legal protection of forests, the important role of the state-owned Austrian Federal Forests in conserving natural resources, and opposition to the privatization of public forests, all significantly influenced the acceptance of and the willingness to pay for programs. These issues especially influenced choices in favor of Program C.

- Interestingly, the overall perception that forests would be a major constituting element of Austria's identity was of less importance than personal experiences regarding forests and variables denoting the policy context.

With respect to the two methodological experiments of the survey, the results partially fulfilled the theoretical expectations. First, the total sample was split into two subsamples of respondents who received payment cards with lower and higher WTP bids, respectively. The results show that doubling the WTP bids on the payment card did not double the mean WTP but rather increased the WTP by roughly $30 \%-50 \%$. This effect of the payment card suggests that the estimated values should be interpreted with caution.

Second, the survey offered half of the respondents (randomly assigned to this subsample) the opportunity to read short stakeholder statements on the different policy programs. The stakeholders 
consisted of two environmental organizations, and two interest groups promoting commercial forestry. Scholars have argued that additional information for the respondents would improve the validity of their stated preferences. However, the influence might go in both directions. The results of this paper with respect to the influence of information regarding stakeholder positions were mixed. The respondents with such information were less likely to accept one of the nature conservation programs. However, the respondents with stakeholder information were also willing to pay more for the realization of Program C, the strict nature conservation scenario.

\section{Conclusions}

In comparison with other recent studies on the value of cultural ecosystem services, especially with regard to the existence values of biodiversity conservation, the WTP elicited in this study is well within the current literature (see e.g., [11,24,25,27-29]). Program B would lead to an increase of naturalness of about $10 \%$; this corresponds to an additional value of $€ 108.25$ per hectare per year compared with the status quo. Program C would increase naturalness by about $25 \%$ and would lead to a corresponding additional value of $€ 112.51$ per hectare per year (compared with the status quo).

The results of this paper indicate that a majority of Austrian households would prefer a change of forest policies towards nature conservation scenarios on publicly owned land. About $60 \%$ of households would even accept a rather strict program that would reduce commercial forestry to a minimum and would lead to nature conservation areas on most of the land, with restrictions of access and some reduction of recreation opportunities in the forests. The advantage of this study is that the questionnaire did not only describe the different scenarios with detailed ecological data but that it included concrete information on the economic consequences of the scenarios offered to the respondents. The current study, therefore, also helps to ascertain consequences for citizens' welfare according to different personal characteristics. It seems that the different programs offered also addressed different perceptions and attitudes of the respondents. If policymakers decide to redesign forest policies, they might want to ensure that they target these different perceptions in the political decision-making processes.

Author Contributions: M.G., J.M., and F.S. conceived of, designed, and performed the survey; M.G. and F.S. analyzed the data; M.G. wrote the original draft; and J.M. and F.S. contributed to reviewing and editing the manuscript.

Funding: Funding of the research program underlying this paper was partially provided by the Austrian Federal Forests (ÖBf).

Acknowledgments: The authors are thankful to the Austrian Federal Forests (Österreichische Bundesforste, ÖBf) for commissioning the research program "Werte der Natur" (Values of Nature) to Vienna University of Technology; within this research program, the survey underlying this paper was performed. We are thankful to G. Plattner and N. Putzgruber of ÖBf and to the whole project team, especially H. Kirchmeir, M. Jungmeier, M. Huber, and E. Kreimer. We are also thankful to the anonymous reviewers for their comments and suggestions. All remaining errors are, of course, the responsibility of the authors.

Conflicts of Interest: The authors declare no conflicts of interest.

\section{Appendix A. Detailed Description of Scenarios of Forest and Nature Development}

\section{Appendix A.1. Description of Program A}

Imagine that the Austrian Federal Forests (ÖBf) were to change their policies; within legal limits, commercial forestry would be intensified so that existing nature conservation areas would be reduced by about one-quarter.

The effects of Program A would be the following:

- the intensification of market-based use of commercial forest with little naturalness (e.g., more frequent clear cutting, fewer mixed forests, more stocks at the same age made up of commercially important tree species); 
- the increase of the commercial use of protected forests in areas where the protective function is not compromised;

- the reduction of natural areas by one-fourth: natural processes may be harmed; small biotopes such as standing or recumbent deadwood, hollow, and nesting trees will be less frequent. Some threatened species (e.g., Eurasian pygmy owl [Glaucidium passerinum], White-backed woodpecker [Dendrocopos leucotos], and Barbastelle [Barbastella barbastellus]) may be regionally extinct. Previously native species such as the Ural owl [Strix uralensis] or the Eurasian lynx [Lynx $\operatorname{lyn} x]$ may not easily be re-introduced into Austrian forests.

- more forestry infrastructure such as forest roads.

- fewer options for recreation activities related to natural forests but improved possibilities owing to a denser network of forest roads.

Owing to higher sales from harvested timber, the annual profits of the Austrian Federal Forests (ÖBf) would increase. The increased funds would be provided to the central government's budget and thus financially relieve Austrian households.

Financial impacts would be as follows:

- the profits of the Austrian Federal Forests would increase to $€ 60 \mathrm{~m}$ (instead of $€ 30 \mathrm{~m}$ as is the case now);

- this increase amounts to an increase of revenues of the federal budget of $€ 10$ per household on average (i.e., your household's annual tax burden would be relieved by $€ 10$ ).

1. Would you agree to the realization of Program A (more intensive forestry, less nature conservation by one-fourth)?

2. What minimum compensation in terms of a relief of your annual tax burden would you demand in order to accept Program A?

\begin{tabular}{ccc}
\hline & \multicolumn{1}{c}{ Split 1 } & Split 2 \\
\hline $\mathrm{O}$ & $€$ 0 per household and year & $€ 0$ per household and year \\
$\mathrm{O}$ & $€ 5$ per household and year & $€ 10$ per household and year \\
$\mathrm{O}$ & $€ 10$ per household and year & $€ 20$ per household and year \\
$\mathrm{O}$ & $€ 15$ per household and year & $€ 30$ per household and year \\
$\mathrm{O}$ & $€ 20$ per household and year & $€ 40$ per household and year \\
$\mathrm{O}$ & $€ 25$ per household and year & $€ 50$ per household and year \\
$\mathrm{O}$ & $€ 30$ per household and year & $€ 60$ per household and year \\
$\mathrm{O}$ & $€ 35$ per household and year & $€ 70$ per household and year \\
$\mathrm{O}$ & $€ 40$ per household and year & $€ 80$ per household and year \\
$\mathrm{O}$ & Another amount: $€ \_$Another amount: $€$. & \\
$\mathrm{O}$ & In any case, I would reject Program A & In any case, I would reject Program A \\
\hline
\end{tabular}

\section{Appendix A.2. Description of Program B}

Imagine that the Austrian Federal Forests (ÖBf) were to change their policies; commercial forestry would be reduced so that the existing nature conservation areas would be extended significantly by about one half with strict nature conservation areas.

The effects of Program B would be the following:

- Reduced intensive forestry in commercial forests, less clear cutting, and more natural forests; not only profitable tree species but also more species diversity;

- The significant reduction of the commercial use of protective forests;

- The reinforcement of nature conservation efforts by about $50 \%$ : dynamic natural processes will be tolerated; biotopes such as standing or recumbent deadwood and hollow and nesting trees will be improved and supported; and some threatened animal species (e.g., Eurasian pygmy 
owl [Glaucidium passerinum], White-backed woodpecker [Dendrocopos leucotos], and Barbastelle [Barbastella barbastellus]) would gain habitats and reproduce faster. Formerly extinct animal species such as the Ural owl [Strix uralensis] or the Eurasian lynx [Lynx $\operatorname{lyn} x$ ] may be reintroduced in Austria.

- No new infrastructure for commercial use (forest roads) will be built; therefore, disturbances for wildlife will be reduced.

- Improved options for nature-based recreation; however, access to some ecologically sensitive areas may be banned.

Owing to reduced sales from harvested timber, the annual profits of the Austrian Federal Forests (ÖBf) would decrease. Thus, the lower revenue would harm the government's budget, and some spending may have to be reduced.

Financial impacts would be as follows:

- Profits of the Austrian Federal Forests would decrease to $€ 10 \mathrm{~m}$ (instead of $€ 30 \mathrm{~m}$ as is the case now);

- This policy reduces the revenues of the federal budget by $€ 6$ per household on average (i.e., your household's annual tax burden would increase by $€ 6$ ).

1. Would you agree to the realization of Program B (less intensive forestry, more nature conservation by about $50 \%)$ ?

2. What would the maximum willingness to pay be in terms of an additional annual tax burden for your household in order to realize Program B?

\begin{tabular}{|c|c|c|}
\hline & Split 1 & Split 2 \\
\hline $\mathrm{O}$ & $€ 0$ per household and year & $€ 0$ per household and year \\
\hline $\mathrm{O}$ & $€ 5$ per household and year & $€ 10$ per household and year \\
\hline $\mathrm{O}$ & $€ 10$ per household and year & $€ 20$ per household and year \\
\hline $\mathrm{O}$ & $€ 15$ per household and year & $€ 30$ per household and year \\
\hline $\mathrm{O}$ & $€ 20$ per household and year & $€ 40$ per household and year \\
\hline $\mathrm{O}$ & $€ 25$ per household and year & $€ 50$ per household and year \\
\hline $\mathrm{O}$ & $€ 30$ per household and year & $€ 60$ per household and year \\
\hline $\mathrm{O}$ & $€ 35$ per household and year & $€ 70$ per household and year \\
\hline $\mathrm{O}$ & $€ 40$ per household and year & $€ 80$ per household and year \\
\hline $\mathrm{O}$ & Another amount: $€$ & Another amount: $€$ \\
\hline $\mathrm{O}$ & In any case, I would reject Program B & In any case, I would reject Program B \\
\hline
\end{tabular}

Appendix A.3. Description of Program C

Imagine that the Austrian Federal Forests (ÖBf) were to change their policies; commercial forestry would be reduced significantly and widely so that the existing nature conservation areas would be doubled.

The effects of Program C would be as follows:

- Little remaining forestry in commercial forests, no clear cutting, and transformation to natural forests and wilderness areas; forests will consist of naturally given domestic tree species, and natural regeneration will take place.

- No commercial forestry will be allowed in protected forests.

- The significant reduction of the commercial use of protected forests; 
- Strong increase of nature conservation efforts: natural processes (growth, regeneration, and vegetation loss) will develop unimpaired on large areas; small biotopes such as standing or recumbent deadwood and hollow and nesting trees would be found throughout forests. Species rare in commercial forests will have the chance to spread widely (e.g., Rosalia longicorn [Rosalia alpina], Stock dove [Columba oenas], Eurasian pygmy owl [Glaucidium passerinum], White-backed woodpecker [Dendrocopos leucotos], and Barbastelle [Barbastella barbastellus]). Many formerly extinct species will again settle in Austria, such as insects specialized in deadwood, the Ural owl [Strix uralensis], or the Eurasian lynx [Lynx lynx].

- The infrastructure for commercial forestry (e.g., forest roads) will be closed down or partially removed; this would lead to a significant reduction of the disturbances of wildlife by humans.

- Significantly improved options for nature-based recreation; however, access to large ecologically sensitive areas would be banned; certain paths would be closed, or it would strictly be forbidden to leave trails. Only a reduced number of forest roads will be open for recreation.

Owing to reduced sales from harvested timber, the annual profits of the Austrian Federal Forests (ÖBf) would decrease. Thus, the lower revenue would harm the government's budget, and some spending may have to be reduced.

Financial impacts would be as follows:

- The Austrian Federal Forests would make a loss of $€ 30 \mathrm{~m}$ per year (instead of making a profit of $€ 30 \mathrm{~m})$;

- This policy reduces revenues of the federal budget by $€ 20$ per household on average (i.e., your household's annual tax burden would increase by $€ 20$ ).

1. Would you agree to the realization of Program C (substantially less intensive forestry, doubling of nature conservation efforts)?

2. What would the maximum willingness to pay be in terms of an additional annual tax burden for your household in order to realize Program C?

\begin{tabular}{ccc}
\hline & \multicolumn{1}{c}{ Split 1 } & Split 2 \\
\hline $\mathrm{O}$ & $€$ 0 per household and year & $€$ 0 per household and year \\
$\mathrm{O}$ & $€ 5$ per household and year & $€ 10$ per household and year \\
$\mathrm{O}$ & $€ 10$ per household and year & $€ 20$ per household and year \\
$\mathrm{O}$ & $€ 15$ per household and year & $€ 30$ per household and year \\
$\mathrm{O}$ & $€ 20$ per household and year & $€ 40$ per household and year \\
$\mathrm{O}$ & $€ 25$ per household and year & $€ 50$ per household and year \\
$\mathrm{O}$ & $€ 30$ per household and year & $€ 60$ per household and year \\
$\mathrm{O}$ & $€ 35$ per household and year & $€ 70$ per household and year \\
$\mathrm{O}$ & $€ 40$ per household and year & $€ 80$ per household and year \\
$\mathrm{O}$ & Another amount: $€ \ldots$ & Another amount: $€$ \\
$\mathrm{O}$ & In any case, I would reject Program C & In any case, I would reject Program C \\
\hline
\end{tabular}




\section{Appendix B. Statements and Opinions of Stakeholders Presented to a Subsample of} the Respondents

\begin{tabular}{|c|c|c|c|}
\hline \multirow{2}{*}{ Stakeholder Group } & \multicolumn{3}{|c|}{ Comments on ... } \\
\hline & Program A & Program B & Program C \\
\hline $\begin{array}{l}\text { WWF World Wide Fund } \\
\text { for Nature }\end{array}$ & $\begin{array}{l}\text { will lead to a irreversible loss } \\
\text { of biodiversity and therefore } \\
\text { has to be rejected especially for } \\
\text { state-owned land. }\end{array}$ & $\begin{array}{l}\text { can improve natural } \\
\text { conditions and nature } \\
\text { conservation. }\end{array}$ & $\begin{array}{l}\text { would support biodiversity, } \\
\text { the regeneration capacity of } \\
\text { forests, and the sustenance of } \\
\text { ecosystem services. }\end{array}$ \\
\hline $\begin{array}{c}\text { Austrian Association of } \\
\text { Environmental NGOs } \\
\text { (UWD) }\end{array}$ & $\begin{array}{l}\text { is in contrast to the } \\
\text { responsibility held by the state } \\
\text { (state-owned land) and } \\
\text { contradicts the Austrian } \\
\text { Biodiversity Strategy 2020+. }\end{array}$ & $\begin{array}{l}\text { represents a multifunctional } \\
\text { forestry; conflicts might occur } \\
\text { with respect to the use of } \\
\text { renewable energy sources. }\end{array}$ & $\begin{array}{l}\text { is an optimal scenario for pure } \\
\text { nature conservation, but the } \\
\text { multifunctional approach may } \\
\text { be reduced for the benefit of } \\
\text { biodiversity conservation. }\end{array}$ \\
\hline $\begin{array}{l}\text { Cooperating platform of } \\
\text { the forest, timber, } \\
\text { and paper industries } \\
\text { (FHP) }\end{array}$ & $\begin{array}{l}\text { is a favorable scenario because } \\
\text { Austria is committed to a } \\
\text { sustainable and } \\
\text { multifunctional forestry. }\end{array}$ & $\begin{array}{l}\text { would have significantly } \\
\text { negative economic effects } \\
\text { owing to the further reduction } \\
\text { of forestry on ÖBf land. }\end{array}$ & $\begin{array}{l}\text { would practically cease forestry } \\
\text { on ÖBf land and would } \\
\text { therefore have catastrophic } \\
\text { economic effects. }\end{array}$ \\
\hline $\begin{array}{l}\text { Association of Austrian } \\
\text { Forestry Companies }\end{array}$ & $\begin{array}{l}\text { would be a reasonable } \\
\text { scenario based on the Austrian } \\
\text { Forest Inventory and would } \\
\text { combine both avoiding climate } \\
\text { change and encouraging } \\
\text { nature conservation. }\end{array}$ & $\begin{array}{l}\text { would be at the disadvantage } \\
\text { of both forestry and } \\
\text { combatting climate change } \\
\text { and would not correspond to } \\
\text { multifunctional forestry. }\end{array}$ & $\begin{array}{l}\text { has to be rejected fundamentally } \\
\text { because it does not help nature } \\
\text { conservation, but would } \\
\text { completely cease forestry. }\end{array}$ \\
\hline
\end{tabular}

\section{References and Notes}

1. Umweltbundesamt. Land Cover and Land Use in Austria; Umweltbundesamt (UBA): Vienna, Austria, 2018.

2. Bundesforstegesetz. Bundesgesetz zur Neuordnung der Rechtsverhältnisse der Österreichischen Bundesforste und Errichtung einer Aktiengesellschaft zur Fortführung des Betriebes “Österreichische Bundesforste", idF. BGBl. I Nr. 136/2004 [Federal act regulating the legal relationships of the Austrian Federal Forests and the establishment of a public limited company as a legal successor; as amended by the Austrian federal register 136/2004], 1996.

3. European State Forest Association. Information and Data on the Members of the European State Forest Association (EUSTAFOR). Available online: https:/ / www.eustafor.eu/eustafor.eu (accessed on 6 June 2018).

4. Weiss, G.; Lawrence, A.; Hujala, T.; Lidestav, G.; Nichiforel, L.; Nybakk, E.; Quiroga, S.; Sarvašová, Z.; Suarez, C.; Živojinović, I. Forest ownership changes in Europe: State of knowledge and conceptual foundations. For. Policy Econ. 2018, in press. [CrossRef]

5. Nichiforel, L.; Keary, K.; Deuffic, P.; Weiss, G.; Thorsen, B.J.; Winkel, G.; Avdibegović, M.; Dobšinská, Z.; Feliciano, D.; Gatto, P.; et al. How private are Europe's private forests? A comparative property rights analysis. Land Use Policy 2018, 76, 535-552. [CrossRef]

6. ÖBf. Nachhaltigkeitsbericht; Österreichische Bundesforste (ÖBf): Purkersdorf, Wien, Austria, 2018.

7. Ministry of Agriculture of the Czech Republic. Information on Forests and Forestry in the Czech Republic by 2012; Ministry of Agriculture of the Czech Republic: Prague, Czech Republic, 2013.

8. Getzner, M.; Gutheil-Knopp-Kirchwald, G.; Huber, M.; Jungmeier, M.; Kirchmeir, H.; Kreimer, E.; Zak, D. Bewertung der Ökosystemleistungen der Österreichischen Bundesforste (ÖBf): “Werte der Natu”-Holz, Tourismus, erneuerbare Energien, Ruhe, Kohlenstoffspeicherung; Research report of the Vienna University of Technology and E.C.O.; Institute of Ecology (Klagenfurt) to the Austrian Federal Forests: Vienna, Austria, 2018a.

9. Dudley, N. Guidelines for Applying Protected Area Management Categories; International Union for Conservation of Nature (IUCN): Gland, Switzerland, 2008.

10. Haines-Young, R.; Potschin, M.B. Common International Classification of Ecosystem Services (CICES) V5.1 and Guidance on the Application of the Revised Structure; European Environment Agency (EEA). Available online: https: / / cices.eu/ (accessed on 7 June 2018).

11. Gantioler, S.; Rayment, M.; ten Brink, P.; McConville, A.; Kettunen, M.; Bassi, S. The costs and socio-economic benefits associated with the Natura 2000 network. Int. J. Sustain. Soc. 2014, 6, 135-157. [CrossRef] 
12. Blicharska, M.; Orlikowska, E.H.; Roberge, J.-M.; Grodzinska-Jurczak, M. Contribution of social science to large scale biodiversity conservation: A review of research about the Natura 2000 network. Biol. Conserv. 2016, 199, 110-122. [CrossRef]

13. Vallet, A.; Locatelli, B.; Levrel, H.; Wunder, S.; Seppelt, R.; Scholes, R.J.; Oszwald, J. Relationships between ecosystem services: Comparing methods for assessing tradeoffs and synergies. Ecol. Econ. 2018, 150, 96-106. [CrossRef]

14. Getzner, M.; Gutheil-Knopp-Kirchwald, G.; Kreimer, E.; Kirchmeir, H.; Huber, M. Gravitational natural hazards: Valuing the protective function of Alpine forests. For. Policy Econ. 2017, 80, 150-159. [CrossRef]

15. Getzner, M.; Meyerhoff, J.; Schläpfer, F. Valuing Forest Management for Local Recreation: The Importance of Quiet and Natural Environments; Mimeo, Vienna University of Technology: Vienna, Austria, 2018b.

16. Johansson, P.-O. Cost-Benefit Analysis of Environmental Change; Cambridge University Press: Cambridge, UK, 1993.

17. Ninan, K.N. (Ed.) Conserving and Valuing Ecosystem Services and Biodiversity; Earthscan: London, UK, 2009.

18. Markussen, M.; Buse, R.; Garrelts, M.; Manez Costa, M.; Menzel, S.; Marggraf, R. Valuation and Conservation of Biodiversity; Springer: Berlin, Germany; New York, NY, USA, 2003.

19. Haines-Young, R.; Potschin, M.; Kienast, F. Indicators of ecosystem service potential at European scales: Mapping marginal changes and trade-offs. Ecol. Indic. 2012, 21, 39-53. [CrossRef]

20. Czajkowski, M.; Buszko-Briggs, M.; Hanley, N. Valuing changes in forest biodiversity. Ecol. Econ. 2009, 68, 2910-2917. [CrossRef]

21. Bartkowski, B.; Lienhoop, N.; Hansjürgens, B. Capturing the complexity of biodiversity: A critical review of economic valuation studies of biological diversity. Ecol. Econ. 2015, 113, 1-14. [CrossRef]

22. Johnston, R.J.; Boyle, K.J.; Adamowicz, W.; Bennett, J.; Brouwer, R.; Cameron, T.A.; Hanemann, W.M.; Hanley, N.; Ryan, M.; Scarpa, R.; et al. Contemporary Guidance for Stated Preference Studies. J. Assoc. Environ. Resour. Econ. 2017, 4, 319-405. [CrossRef]

23. Soliva, R.; Hunziker, M. How do biodiversity and conservation values relate to landscape preferences? A case study from the Swiss Alps. Biodivers. Conserv. 2009, 18, 2483-2507. [CrossRef]

24. Bopa, B.; Pascu, M.; Niță, D.M.; Borz, S.A.; Codreanu, C. The value of forest ecosystem services in Romanian protected areas-A comparative analysis of management scenarios. Bull. Transilvania Univ. Braşov. For. Wood Ind. Agric. Food Eng. Series II 2013, 6, 53-62.

25. Bösch, M.; Elsasser, P.; Franz, K.; Lorenz, M.; Moning, C.; Olschewski, R.; Rödl, A.; Schneider, H.; Schröppel, B.; Weller, P. Forest ecosystem services in rural areas of Germany: Insights from the national TEEB study. Ecosyst. Serv. 2018, 31, 77-83. [CrossRef]

26. Ciesielski, M.; Stereńczak, K. What do we expect from forests? The European view of public demands. J. Environ. Manag. 2018, 209, 139-151. [CrossRef] [PubMed]

27. Nielsen, A.B.; Olsen, S.B.; Lundhede, T. An economic valuation of the recreational benefits associated with nature-based forest management practices. Landsc. Urban Plan. 2007, 80, 63-71. [CrossRef]

28. Weller, P.; Elsasser, P. Preferences for forest structural attributes in Germany-Evidence from a choice experiment. For. Policy Econ. 2018, 93, 1-9. [CrossRef]

29. Rambonilaza, T.; Brahic, E. Non-market values of forest biodiversity and the impact of informing the general public: Insights from generalized multinomial logit estimations. Environ. Sci. Policy 2016, 64, 93-100. [CrossRef]

30. Jagger, P.; Luckert, M.K.; Duchelle, A.E.; Lund, J.F.; Sunderlin, W.D. Tenure and forest income: Observations from a global study on forests and poverty. World Dev. 2014, 64, S43-S55. [CrossRef]

31. Czajkowski, M.; Bartczak, A.; Budziński, W.; Giergiczny, M.; Hanley, N. Preference and WTP stability for public forest management. For. Policy Econ. 2016, 71, 11-22. [CrossRef]

32. Schläpfer, F. Access to party positions and preference formation: A field experiment. Swiss Political Sci. Rev. 2011, 17, 75-91. [CrossRef]

33. Getzner, $\mathrm{M}$. The regional context of infrastructure policy and environmental valuation: The importance of stakeholders' opinions. J. Environ. Econ. Policy 2012, 1, 255-275. [CrossRef]

34. Czajkowski, M.; Bartczak, A.; Giergiczny, M.; Navrud, S.; Żylicz, T. Providing preference-based support for forest ecosystem service management. For. Policy Econ. 2014, 39, 1-12. [CrossRef] 
35. Juutinen, A.; Kosenius, A.-K.; Ovaskainen, V.; Tolvanen, A.; Tyrväinen, L. Heterogeneous preferences for recreation-oriented management in commercial forests: The role of citizens' socioeconomic characteristics and recreational profiles. J. Environ. Plan. Manag. 2016, 60, 399-418. [CrossRef]

36. Getzner, M.; Getzner, M.; Gutheil-Knopp-Kirchwald, G.; Huber, M.; Jungmeier, M.; Kirchmeir, H.; Kreimer, E.; Zak, D. Bewertung der Ökosystemleistungen der Österreichischen Bundesforste (ÖBf): “Werte der Natur"-Wasserversorgung, Erosionsschutz, lokale Klimaregulation Erholungsleistung, Biologische Vielfalt; Research Report of the Vienna University of Technology and E.C.O.; Institute of Ecology (Klagenfurt) to the Austrian Federal Forests: Vienna, Austria, 2016. article distributed under the terms and conditions of the Creative Commons Attribution (CC BY) license (http:/ / creativecommons.org/licenses/by/4.0/). 